\title{
Safe and smart savings for vulnerable girls in Kenya and Uganda: The evolving model, lessons learned, and recommendations
}

\author{
Karen Austrian \\ Population Council \\ Eunice N. Muthengi \\ Population Council \\ Angela Wambugu \\ Dennitah Ghati \\ Population Council \\ Elizabeth Kariuki
}

Follow this and additional works at: https://knowledgecommons.popcouncil.org/departments_sbsr-pgy

Part of the Family, Life Course, and Society Commons, and the Gender Equity in Education Commons How does access to this work benefit you? Let us know!

\section{Recommended Citation}

Austrian, Karen, Eunice N. Muthengi, Angela Wambugu, Dennitah Ghati, and Elizabeth Kariuki. 2012. "Safe and smart savings for vulnerable girls in Kenya and Uganda: The evolving model, lessons learned, and recommendations," Program brief. Nairobi: Population Council. 


\section{SAFE AND SMART SAVINGS FOR VULNERABLE GIRLS IN KENYA AND UGANDA}

THE EVOLVING MODEL, LESSONS LEARNED, AND RECOMMENDATIONS

KAREN AUSTRIAN, EUNICE MUTHENGI, ANGELA WAMBUGU, DENNITAH GHATI, AND ELIZABETH KARIUKI

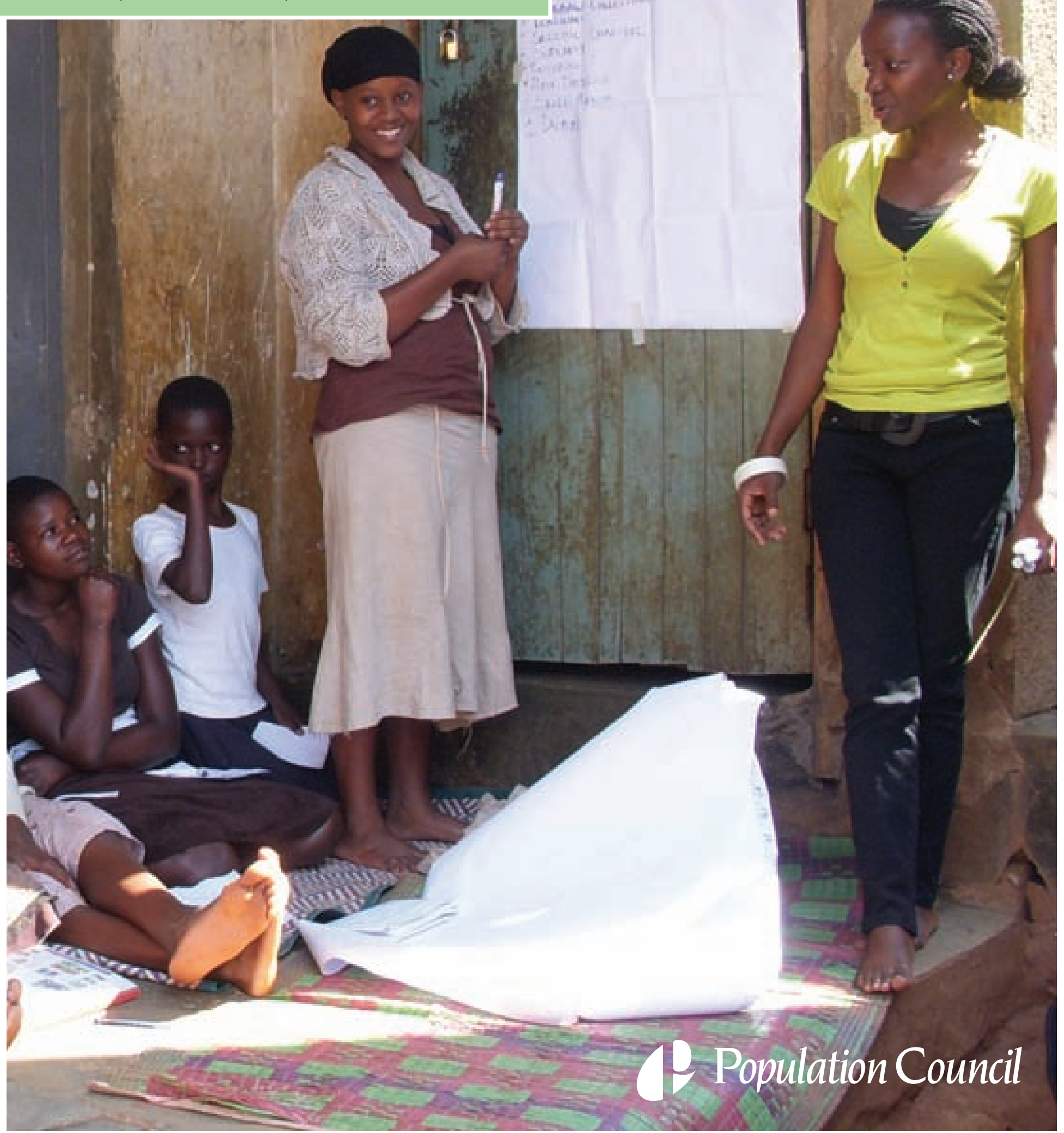




\section{Population Council}

The Population Council confronts critical health and development issues-from stopping the spread of HIV to improving reproductive health and ensuring that young people lead full and productive lives. Through biomedical, social science, and public health research in 50 countries, we work with our partners to deliver solutions that lead to more effective policies, programs, and technologies that improve lives around the world. Established in 1952 and headquartered in New York, the Council is a nongovernmental, nonprofit organization governed by an international board of trustees.

(C) 2012 The Population Council, Inc.

Population Council

One Dag Hammarskjold Plaza

New York, NY 10017 USA

Tel: 212-339-0500

Fax: 212-755-6052

http://www.popcouncil.org

Karen Austrian is an Associate and Eunice Muthengi and Dennitah Ghati are Program Officers at the Population Council. Angela Wambugu is a Financial Systems Consultant and Elizabeth Kariuki is an Analyst at MicroSave Consulting, Ltd. 


\section{INTRODUCTION}

Economic independence, especially for girls, is critical for making sound decisions and translating health knowledge into positive behavior change. As adolescent girls grow and take on additional personal and household responsibilities, their need to access money increases. Early adolescence is the time to build critical moneymanagement skills and develop savings habits that will help girls meet short-term goals and daily financial needs, mitigate the effect of household emergencies, and plan for a healthier, more stable future.

To make a healthy and safe transition to adulthood-completing school, remaining HIVnegative, avoiding unwanted pregnancies, and finding a meaningful livelihood-adolescent girls require a combination of social, health, and economic assets. Just focusing on one of these areas does not provide the skills and knowledge needed to overcome the daily challenges girls face. Therefore, in June 2008 the Population Council and MicroSave Consulting Ltd. started "Safe and Smart Savings Products for Vulnerable Adolescent Girls." The overall aim of the program was to develop, pilot test, and roll out savings accounts for girls with four financial institutions, two in Kenya and two in Uganda. With support from the Nike Foundation and the Financial Education Fund, the Population Council and partners de-

signed, implemented, and evaluated a three-part program to reach vulnerable girls and help build assets through: 1) weekly group meetings led by a female mentor from their community,

2) financial education and basic health education, and 3) a formal savings account.

This brief provides the following: a description of the program model and how it evolved from the pilot to the rollout phases from Kenya to Uganda, bank utilization data on the savings accounts, the girls' feedback on their experiences with the program, lessons learned, and a look ahead.

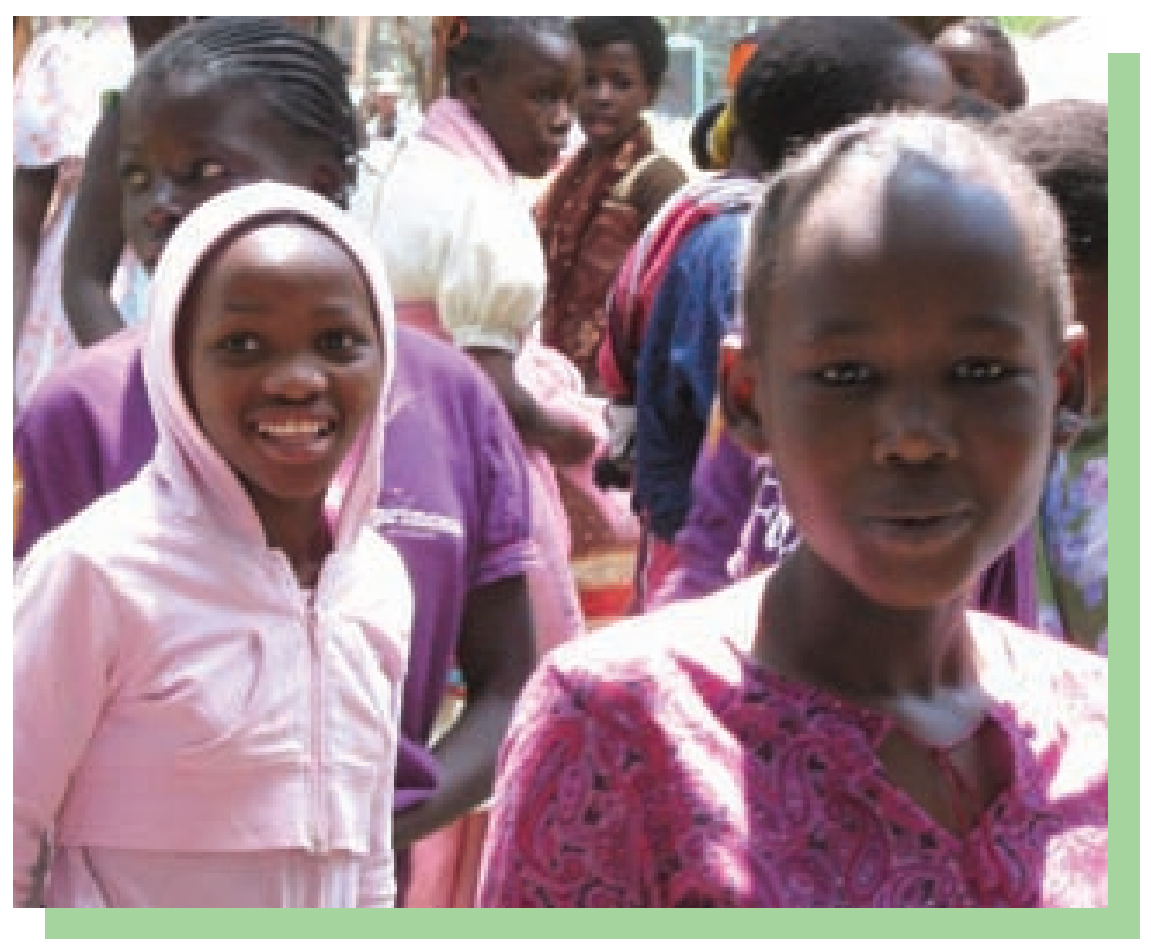




\section{PROGRAM BACKGROUND}

In June 2007, the Population Council commissioned MicroSave to conduct a market research study to assess the feasibility of a savings account for vulnerable girls in Nairobi's slum areas. The Council believed that a move toward savings accounts for girls was appropriate because: 1 ) an earlier program adapting microcredit to adolescent girls showed that girls wanted the ability to save independently from their loans (and, regardless, many were not ready for credit) ${ }^{1}$; 2) girls in health- and leadership-focused programs were often unable to translate their knowledge about health into practice because of their economic situation; and 3 ) initial financial education programs were very popular with the girls, and they (and their parents) were requesting a safe place to store their money.

At that time, the only "child accounts" that existed were operated by a guardian in the name of a child, not accounts that adolescents could operate themselves. Key findings from the initial market research study were: 1) girls had money; 2) if appropriately designed savings accounts were available, girls would save their money in them; and 3) girls wanted health and social activities as well as the opportunity to save. Based on the market research and prior experience with developing programs for adolescent girls, a product concept for a group-based savings account was developed; the group model addressed the legal con-

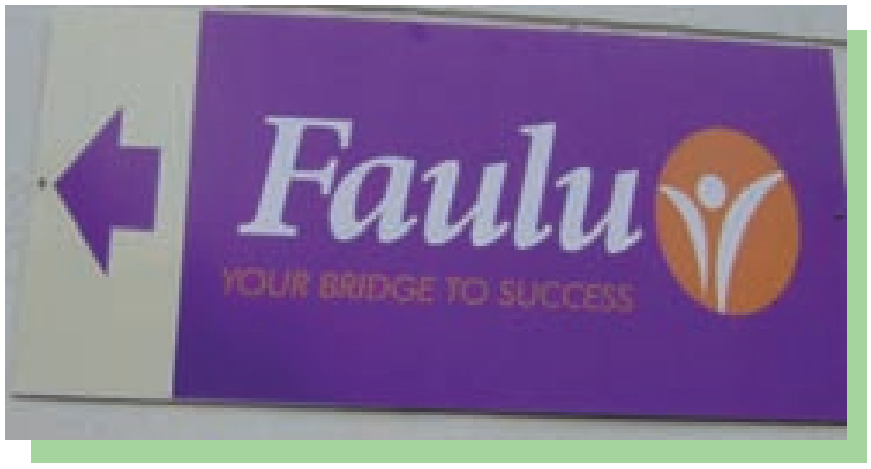
straints of minors not being able to hold individual accounts and provided the girls with access to the "Safe Spaces" model of programming, building their social networks.

In June 2008, partnerships were formed with two financial institutions in Kenya-Faulu-Kenya and K-Rep Bank. Using the market research, an individual savings account was developed at each institution, the concept was tested with the target population, and preparations were made for pilot testing.

\section{SAFE AND SMART SAVINGS MODEL}

The asset-building framework for vulnerable adolescent girls is the theoretical underpinning guiding this intervention. Assets are a store of value that girls can use to both reduce vulnerabilities and expand opportunities. For example, self-esteem is an asset. A girl can draw on her self-esteem to negotiate for safer sex (reduce vulnerabilities) or to excel at a job interview (expand opportunities). Another example of an asset is savings. A girl can use her savings in the event of illness in the family to pay hospital bills, instead of getting the money in a risky way (reducing vulnerabilities). Savings can also pay for a vocational training course (expand opportunities).

This theory of change posits that girls need a combination of social, health, and economic assets to make a healthy transition into adulthood, which in turn will reduce poverty. Having one kind of asset (i.e., knowledge of HIV and pregnancy) is not sufficient, because often a girl's economic situation overshadows her knowledge of risky behavior. Similarly, only having a savings account or a vocational skill is not enough for girls to take control of their health or to have the self-esteem and networks through which to capitalize on economic opportunities.

\footnotetext{
Erulkar, Annabel and Erica Chong. 2005. Evaluation of a Savings \& Micro-Credit Program for Vulnerable Young Women in Nairobi. Nairobi: Population Council.
} 
Therefore, Safe and Smart Savings Products for Vulnerable Adolescent Girls is not just a savings account but, rather, a program that provides financial and nonfinancial services to ensure that girls build all three sets of assets. First, girls belong to a group made up of 15-25 individuals. Each group meets once a week and is led by a mentor-a young woman who comes from the same community as the girls. During the pilot period, mentors were volunteers who served as both cosigners on the bank accounts (because the girls were younger than 18) and group leaders. The mentors were selected by the girls and supervised by the field officers from Faulu Kenya and K-Rep. Girls received training on financial education and basic health education. In addition to these services, the girls were assisted in opening a savings account.

By law in both Kenya and Uganda, one cannot open a savings account until the age of 18 , thus an adult was needed to be a cosigner, to participate in the account-opening process, and to assist with withdrawals. Girls could make deposits on their own, and the cosigner could not make withdrawals without the girl being present. During the pilot program in Kenya and Uganda, the cosigner could be any female adult over the age of 18 selected by the girl.

Safe and Smart Savings Products for Vulnerable Adolescent Girls is not just a savings account but, rather, a program that provides financial and nonfinancial services to ensure that girls build social, health, and economic assets.

\section{ROLLOUT OF SAVINGS PROGRAM}

"Child accounts" as a category are not known to be profitable as standalone products, and the girls' savings account was not expected to be profitable. However, the financial institutions were interested in pursuing girls' savings accounts for three main reasons: 1) the institutions could build a future customer base, and if they developed customer loyalty now, the girls would likely continue to be clients of the bank into their adult years; 2) the girls' families and communities were a potential "unbanked" client base that the financial institutions could market through the girls; and 3) the girls savings accounts would improve the image of the financial institutions and serve partially as a corporate social responsibility project. The financial institution partners were open to integrating financial education into the group meetings and saw the direct benefit it would have in helping the girls become better savers.

During the pilot period, the accounts were "no fee"-meaning they could be opened with no minimum balance, and there were no monthly fees or fees to make a withdrawal or deposit. The pilot launched in Nairobi in December 2008 with approximately 500 girls per financial institution.

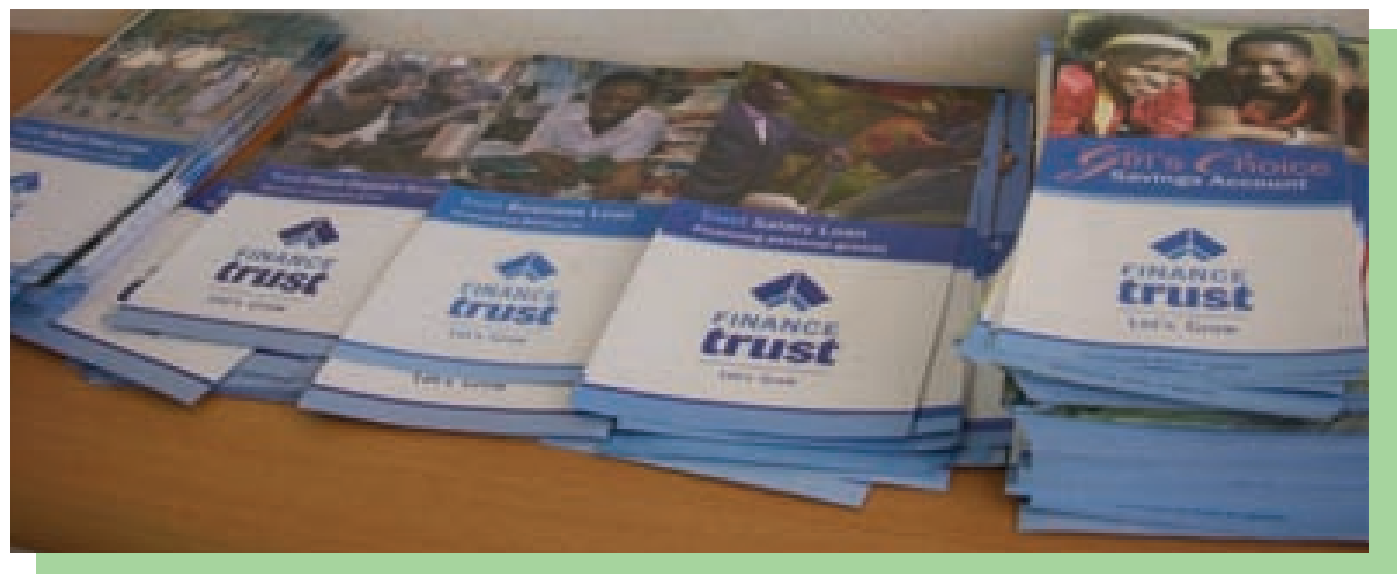


In June 2009, market research began in Uganda. Population Council and MicroSave teams were joined by staff from two financial institutions: Finance Trust and FINCA-Uganda. A similar product development process was followed, built on lessons learned from Kenya. One key change made in the Ugandan pilot was the separation of functions for the mentor. In Kenya, the same mentor was both a signatory on the account and a group facilitator. However, because that led to irregularities in depositing when the girls gave the mentors money to deposit without any controls from the financial institution, in Uganda girls selected a "financial

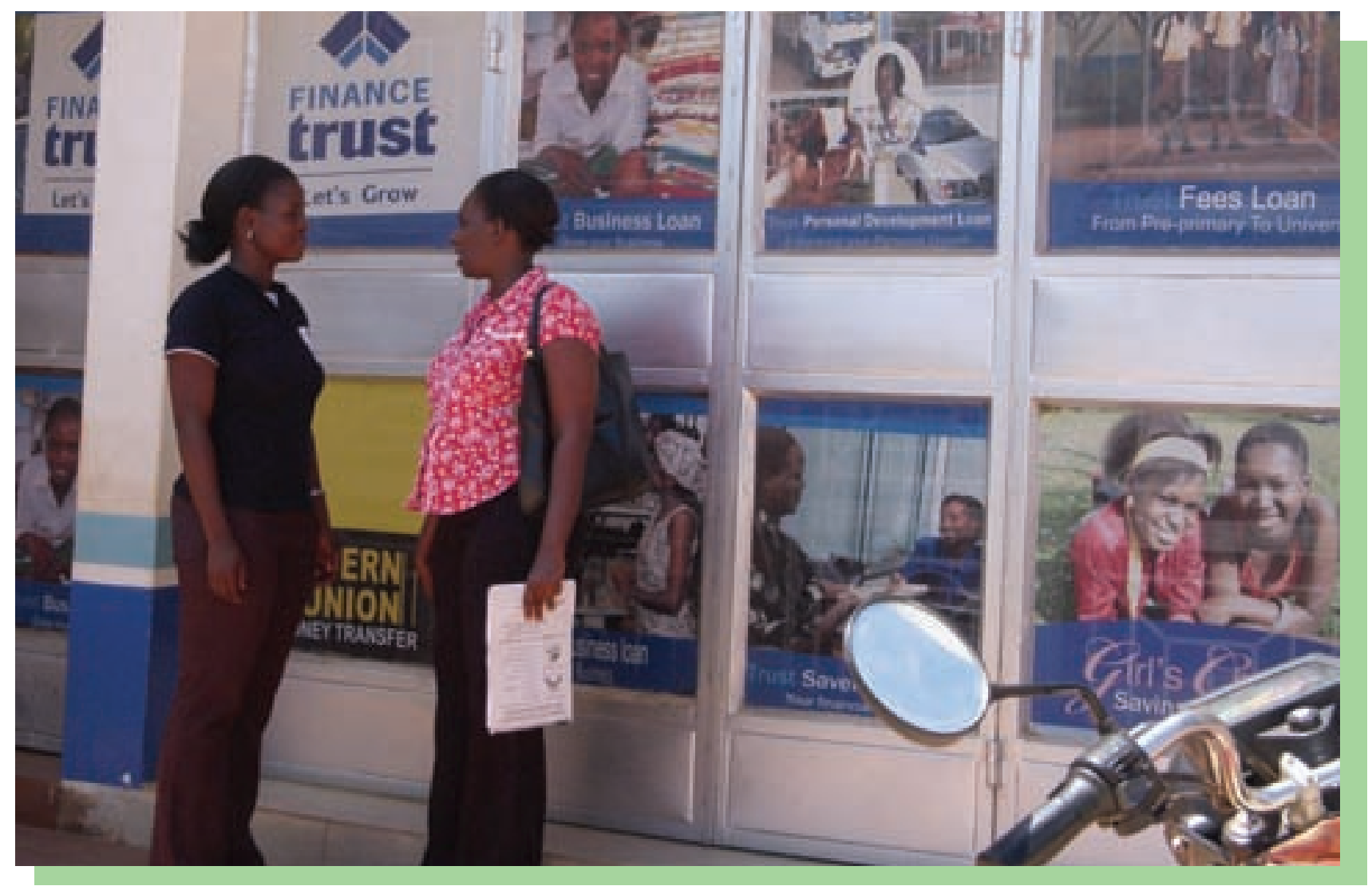

mentor" who was the cosigner needed for account opening and withdrawals, and a second "social mentor" was identified by the bank staff to facilitate the weekly group meetings.

After a year of piloting in each country, activities moved into the rollout phase. In Kenya, K-Rep moved into two additional branches and Faulu aimed to reach wider coverage within Kibera. In Uganda, Finance Trust expanded to four additional branches (for a total of six) and FINCA to two additional branches (for a total of four). However, critical changes were made to the program model. During the pilot, the banks were responsible for managing both the financial and nonfinancial services, with guidance from the Population Council. This was determined to not be the best arrangement, for the following reasons: 1) training and girls programming are not the core capacity of the banks; 2) it is too much work for one bank field officer; and 3) the nonfinancial services have ongoing operating costs, whereas the bank accounts largely had only start-up costs. The banks were not willing to incur the ongoing costs of the nonfinancial services once the funding to subsidize the pilot was over. In addition, due to the voluntary nature of the mentor position, there were problems with inconsistent attendance. Therefore, during the rollout, community groups were identified in each branch area to manage the nonfinancial service component of the model and were trained and guided by the Population Council. The community-based organizations recruited mentors, who were now paid a small stipend, and oversaw the recruitment of girls, formation of girls groups, and 
delivery of health and financial education. The change in the model led to a much more successful delivery of the full model during the rollout period and allowed each partner to work within their core capacity.

As of November 2012, more than 10,000 girls in Kenya and Uganda had opened accounts with one of the four financial institutions and/or been part of the group-based financial education sessions. Finance Trust opened more than 4,600 accounts, accumulating $\$ 62,000$ in savings, and girls had an average balance of $\$ 13.50$ in their accounts. FINCA had more than 1,920 accounts, accumulating $\$ 18,000$, with an average balance of $\$ 9.60$ per account. K-Rep had 2,202 accounts and more than $\$ 12,000$ in savings. Faulu had 1,384 accounts and more than $\$ 6,500$ in savings.

\section{PROGRAM IMPACT}

The overall aim of the program evaluation is to understand the design and performance of the account from the financial institution's perspective, and to measure the social, economic, and health effects of participating in these financial and non-financial services on the girls themselves. Several methods were used to evaluate the program. First, girls from the pilot period were followed for two years and interviewed at baseline, after one year, and after two years. The survey covered a range of topics, including: demographics, education status, living arrangements/asset holding, work and savings activities, financial literacy, social networks and vulnerability, self-esteem, gender norms, relationships and communication with parents, future goals, HIV/RH knowledge, and basic sexual behavior. The full evaluation findings from this study will be available in a complementary report; initial analysis from the second round of data collection indicated positive gains for girls in some measures of social networks and mobility, gender norms, financial literacy, use of bank services, savings behavior, and communication with parents/guardians on financial issues. In addition, in Uganda there were girls who received savings accounts but were not assigned to a girls' group, and there were findings after the second round of data collection indicating that whereas both sets of girls were able to build economic assets, the girls assigned to groups had better social and health assets after one year from baseline.

As of November 2012, more than 10,000 girls in Kenya and Uganda had opened accounts with one of the four financial institutions and/or been part of the group-based financial education sessions.

\section{PROCESS EVALUATION}

At the end of the rollout period, qualitative data was collected from girls of all ages at all branches, and from parents, mentors, and bank staff, to assess the overall experience of and satisfaction with the savings account and the financial and health education.

\section{Financial education}

Overall, girls who received financial education training said they learned the importance of saving regularly in a safe place such as a bank, in order to be prepared for emergencies and future needs. They learned that they needed a savings plan and savings goals-both longterm and short-term-to motivate them to keep saving. Girls also learned how to manage money by differentiating needs and wants and by controlling spending so as not to misuse 
money. In addition, girls reported that they were able to identify their talents and to start planning how to achieve their dreams.

A substudy was conducted during the rollout period in both Kenya and Uganda. In each country, girls in one branch were taught financial education through a traditional trainers' guide that included a savings diary with at-home activities related to each session. Girls in the second branch were given a workbook that used self-facilitation techniques and was less dependent on the mentor's delivering of financial education lessons. After one year, it appeared that girls from the different delivery channel mechanisms, in both countries, had similar levels of financial literacy on key indicators including: short- and long-term financial goals, knowledge and use of savings plans, knowledge and use of budgets, and knowledge of banking services. These results have implications for future delivery of financial education and the ability to use less time and resources than required by face-to-face delivery methods.

Overall, the teaching methods used to train girls on financial education included group discussions, lectures by mentors, use of workbooks/diaries, visual aids, homework assignments, role-playing, and drama. Girls liked these teaching methods because they were participatory, fun, interesting, and inspiring. They enjoyed the flexibility of being able to ask questions and express themselves during the trainings. Girls also liked the ability take their workbooks home and learn independently, in case they missed a meeting. On the other hand, some girls did not like the fact that the workbook included answers in the back, which encouraged cheating on assignments. They also mentioned that mentors sometimes lectured too quickly, without allowing for questions and discussion. At times, mentors repeated information for the sake of girls who missed a previous class; the other girls found it boring to listen to the same information a second time.

Overall, most financial education topics were understood, accepted, and appreciated by the girls who participated in the program. The teaching methods and materials inspired interest and motivated girls to continue learning outside of group meetings. However, some of the topics and concepts were difficult for mentors to teach and for the girls to understand. Possible suggestions to address these issues include providing more simplified training tools in which difficult concepts are explained using simpler language. Difficult topics can also be reviewed after covering the course content to ensure that girls have understood the main points. The girls' concerns about inclusion of answers at the back of the workbook could be addressed by providing separate answer booklets or guides for the mentors.

"Why Save?" gave me a reason why I should save and how I should save, and it also helped me control my spending. I used to spend my money on things like samosas." UGANDAN GIRL, AGE 15-19, KITINTALE "I have learned to dream big, FINCA has taught me to dream bigger. Before I would dream about picking money which has been lost from people, but now I dream of becoming a doctor and making my money."
"Planning my savings by writing down what I want to do with my money and drawing the line between needs and wants."

KENYAN GIRL, AGE 15-19, KIBERA.

"I never used to persevere. I used to spend all my money, but these days I know how to save."

KENYAN GIRL, AGE 10-14, LUNGA LUNGA

"You must know why you are saving and must have a plan. Don't save just because people are saving."

KENYAN GIRL, AGE 10-14, LUNGA LUNGA 


\section{Sexual and reproductive health}

In addition to financial education, girls were trained on sexual and reproductive health topics, which participants found mostly useful. Girls especially liked the following topics: 1) HIV/ AIDS, 2) hand washing and cleanliness, 3) boy-girl relationships, 4) teenage and unwanted pregnancies, 5) setting life goals, and 6) adolescent growth and development. Ugandan girls also found family planning lessons useful, while Kenyan girls liked the lessons on the importance of living in peace. Of these topics, the lessons that girls were most able to implement into their daily lives were: sexually transmitted infections (STIs) including HIV/AIDS, boy/girl relationships, and hygiene.

Girls reported that they learned how to protect themselves from contracting sexually transmitted diseases and HIV by abstaining from sex, being careful not to share sharp objects, and practicing good hygiene. Girls also learned the importance of knowing their status by getting tested. Lessons about stigma encouraged girls to be tolerant of people living with HIV/AIDS. Girls, parents, and project staff reported changes in the way girls related to boys. They mentioned that girls learned how to have healthy relationships with boys and to dif-

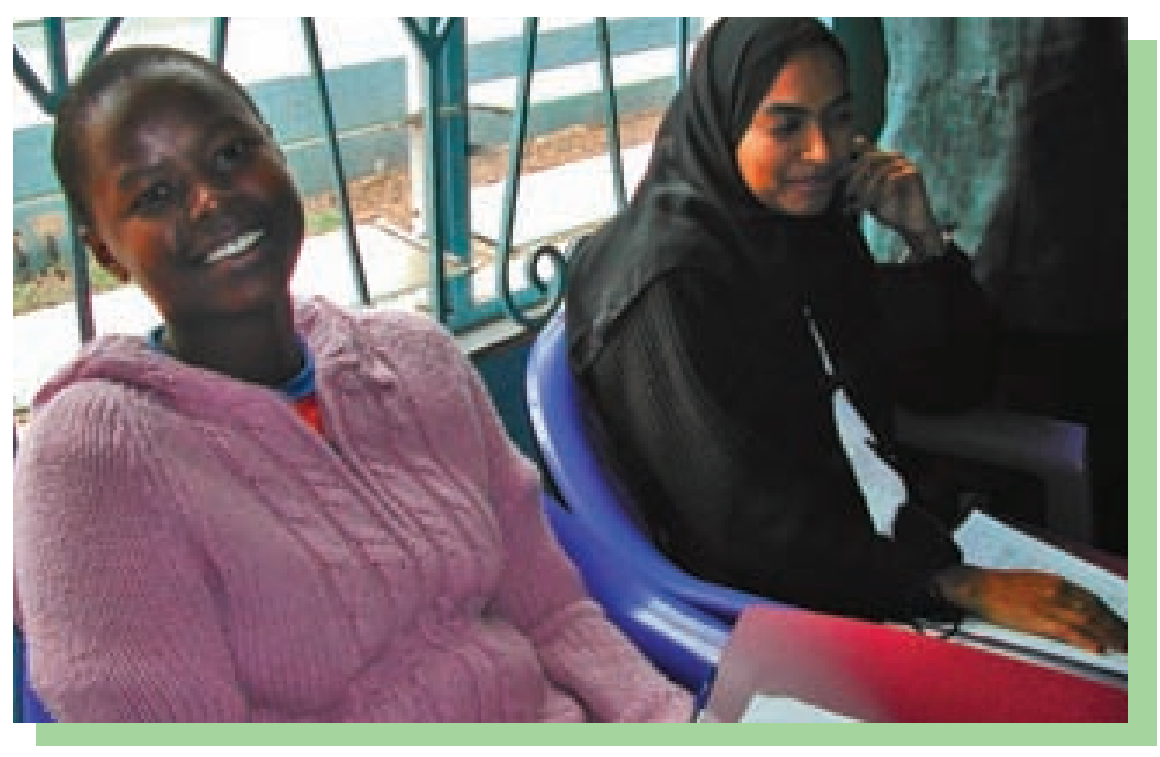
ferentiate between friends and boyfriends. They also learned how to handle attention from boys and which types of boys to trust. Some girls were said to be more responsible because they started coming home on time, rather than visiting discos or going out to meet boys.

Practicing good hygiene was one of the most commonly mentioned changes observed in girls who participated in the program. Program staff, mentors, and parents observed that girls were much cleaner than they used to be. Girls stated that they now washed their hands regularly, bathed, washed their undergarments and clothes, and kept their environments clean.

Other lessons that girls were able to put into practice included family planning and preventing unwanted pregnancy. Girls learned about the changes happening in their bodies, including menstruation, and this helped them better understand themselves and control their behavior. The information they gained about drugs and unwanted pregnancy enabled them to avoid environments, situations, and people who might tempt them to engage in risky behaviors.

One key change recommended was that the SRH curriculum be more tailored to the two age groups-10-14 and 15-19. The girls and mentors felt that several topics were not appropriate for the younger girls.

"Before, if a boy says you are beautiful you start dressing badly not knowing that will get you in trouble. But now, if they say you are beautiful you say, 'I know.' "

KENYAN GIRL, AGE 10-14, LUNGA LUNGA
"I learned how to practice proper sanitation. I would shower some parts of the body and lie to my mother that I had taken a full shower, but now I shower without being told by my mother." 


\section{Savings accounts}

The girls provided feedback on their savings account. They mentioned several features that they liked, including the fact that the accounts were tailored toward them, they did not require a minimum deposit, there were no fees, they could deposit small amounts of money, and they could make unlimited deposits and withdrawals. Having a savings account encouraged girls to be more disciplined in their saving. In general, girls liked the security associated with the accounts because they knew their money was being kept safely for their future needs and expenses. In Uganda, girls mentioned that the staff at the banks were friendly and provided good customer service.

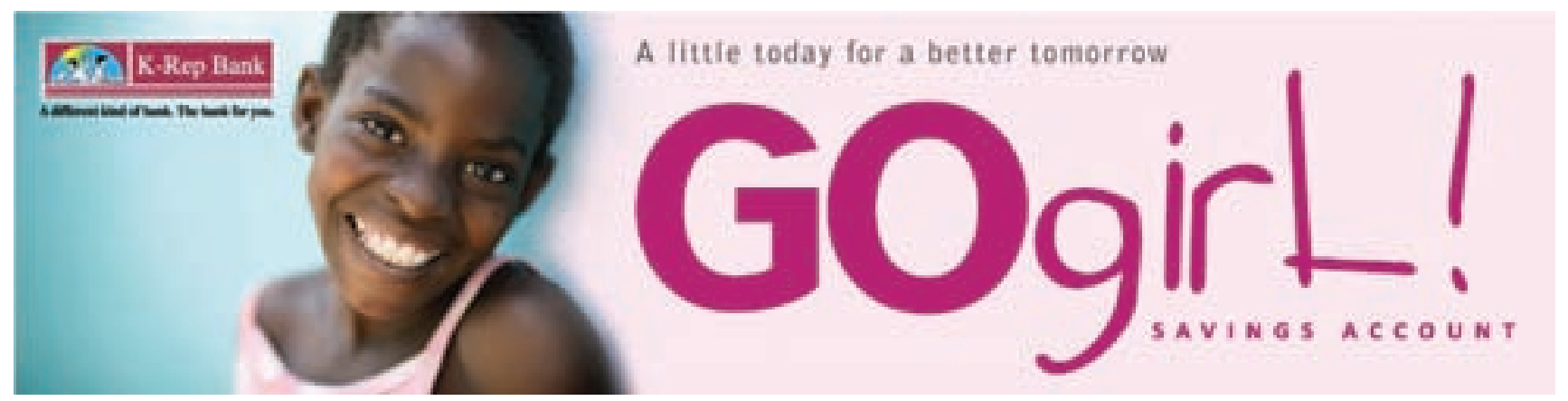

Respondents described some risks that may be increased by girls' access to savings accounts. These include parents or guardians taking girls' money without their consent or borrowing money without refunding it, parents not providing for girls' needs, harassment from boys, and the possibility of girls engaging in risky behaviors in order to acquire money for saving. These risks were only mentioned by girls who participated in Safe Spaces groups. Ugandan girls who were not in groups only discussed the potential danger of money being stolen by strangers, which was not directly associated with the savings accounts. Strategies to reduce these risks include educating parents, helping parents set up their own accounts, engaging boys, and providing training or opportunities for girls to earn money legitimately.

Many respondents mentioned that savings accounts can help reduce risks and vulnerability by enabling them to refuse sexual advances from men, allowing them to be less dependent on men, and helping them to be prepared for daily needs and family emergencies. Girls reported that having access to financial assets increased their confidence and ability to refuse sexual advances, and helped them avoid being deceived by men and having to exchange sexual favors to obtain money. They felt more economically independent as a result of having an account. Having a savings account also reduced vulnerability by enabling girls to meet their day-to-day needs. This included purchasing sanitary towels and school uniforms as well as paying for household expenses such as food, school fees, and hospital costs. Girls expressed a sense of pride at being able to help their families in times of need.

In general, girls liked the security associated with the accounts because they knew their money was being kept safely for their future needs and expenses.
In general the savings accounts were designed to meet girls' needs and were easy for them to understand and use. Although having savings accounts could potentially increase some risks of being taken advantage of by parents or being harassed by boys, the accounts help to reduce risks and vulnerabilities for girls. Girls with savings are more economically independent and less likely to rely on men for money to meet their needs. 
"What attracted me is that saving is very helpful because it minimizes chances of boys taking advantage of us in the disguise of giving us money."

UGANDAN GIRL, AGE 10-14, KATWE

"Personally I joined because at times I can be having a problem and my mother might not have money at the time. Then I can help myself out instead of seeking help from a boy, who will later ask for his money."

UGANDAN GIRL, AGE 10-14, KATWE

"Also help around my parents if they don't have money, and if my sibling fell sick I can get money from my account and they take her to hospital."

UGANDAN GIRL, AGE 10-14, KATWE
"My mum was sick and my dad did not have money, so we went and withdrew my money and cleared my mum's hospital bill. It feels good."

KENYAN GIRL, AGE 10-14, KIBERA

"Sometimes a boy can tell you, "let me hold your hand, then I will give you 50 bob.' You then tell them, 'I have more than that 50 bob you want to give me.' "

KENYAN GIRL, AGE 10-14, KAWANGWARE

"Today no boy can come to me, what can he give to me anyway? They can't even give you 100,000, and I already have it on my account. So I just chase them off because I don't see any use of such [boys] to me anymore."

UGANDAN GIRL, AGE 15-19, KATWE

\section{IMPLEMENTATION CHALLENGES AND RECOMMENDATIONS}

Based on the program experience from both the pilot and rollout phases in two countries, there are several overarching programmatic lessons that have been learned beyond the detailed lessons described above, and recommendations for replication.

\section{COMBINING FINANCIAL AND NONFINANCIAL SERVICES}

Maintaining a program model that has both financial and nonfinancial services is more costly than simply offering a savings account. While the banks can continue to offer the savings accounts and can cross-subsidize the cost of the "no fee" nature of the account through other revenue sources, it is likely that the nonfinancial services will need ongoing subsidy. One potential source of this subsidy is a bank's corporate social responsibility department, however they may not be best suited to manage activities for vulnerable girls (see below). Alternatively, banks can partner with existing programs that reach girls to enhance their activities with savings and financial education, or programs that reach adolescent girls can ask banks to add a savings and financial education component to their work. By the end of the rollout phase, this balance was achieved as follows-financial institutions offered the savings accounts; community-based organizations recruited and supervised the mentors, and man- 
aged the weekly group meetings and financial and health education trainings; MicroSave provided technical support on the management and evaluation of the savings accounts; and the Population Council provided technical support to the community-based organizations on the girls' program, including training of mentors and provision of appropriate financial and health education materials.

\section{ENGAGE MULTIPLE LEVELS OF FINANCIAL INSTITUTION STAFF}

As expected, there were varying levels of success within each of the four financial institutions. In cases where the account became the responsibility of one individual within the institution, there was less success, because the individual often lacked the institution's support to prioritize these activities. In the cases where the uptake of the girls' savings accounts was smoothest and integrated into the institution's line of products, there was full engagement, from the start and on an ongoing basis, with a range of staff-including the managing director, other members of senior management, branch managers, and field staff.

\section{ADDRESS “KNOW YOUR CUSTOMER" REQUIREMENTS AT AN EARLY STAGE}

One major challenge that emerged during the rollout, especially in Kenya, was the issue of Know Your Customer (KYC) requirements. The Central Bank of Kenya tightened requirements on minors' accounts, restricting account opening to those who had formal identity documentation as well as a cosigner/financial mentor who is either a parent or formal guardian who also has the documentation to prove it. As a result, the number of girls who were able to open accounts was limited. In certain cases, only half the girls who joined the program and wanted to open accounts were able to do so. The girls who were not able to open accounts were likely those who are the most vulnerable-therefore, they did not have the necessary identification or a parent or formal guardian to cosign for them.

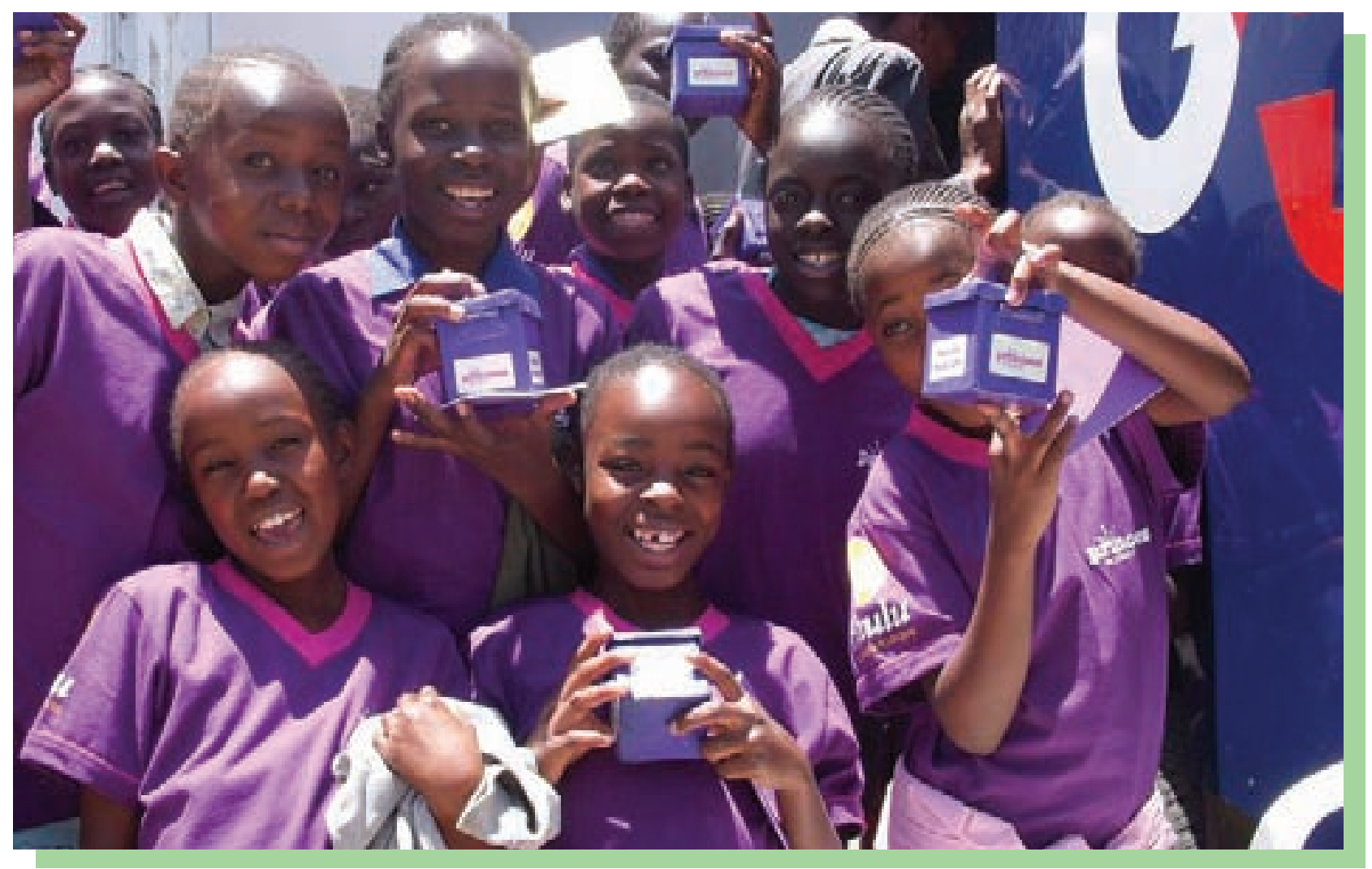


It is recommended that KYC requirements are addressed up front, during the development of accounts for minors. A financial institution must be willing to take a small amount of risk if they want to reach this population. In addition, the financial institution should consider advocacy at the Central Bank level to obtain approvals for the account profile, including KYC specifications. Finally, when financial inclusion for this population is a priority at national levels, then the Central Banks themselves must look at the KYC policies and make the necessary adjustments, while still taking risk-mitigation measures, so that vulnerable girls (and boys as well) can be reached with financial services.

\section{CONCLUSION/NEXT STEPS}

The first phase of Safe and Smart Savings Products for Vulnerable Girls, funded by the Nike Foundation and the Financial Education Fund, is coming to a close in December 2012. The financial institutions have chosen a range of approaches to continue with the account and activities that had been running for the past several years. Two of the banks are merging or adapting the product profile with other minors' accounts so that they will now be available to both boys and girls. They will attempt to continue the financial education through corporate social responsibility or other grant-funded activities going on at the institution. Two other banks are retaining the account as a girls-only account and will be continuing to expand into additional branches outside the capital city. The Council will continue supporting the nonfinancial services, identifying and training local organizations that can or are already working with girls, to partner with the banks for this added service. The Council will also continue to research the relationship between economic assets, specifically savings, and sexual exploitation.

A savings account that is accessible to vulnerable girls and is coupled with an enabling programming platform that builds social and health assets in addition to economic assets is a powerful intervention for adolescent girls. Savings provides a cash reserve that promotes independence and lessens risky dependency, and helps girls develop a future orientation through financial and nonfinancial goal setting. Through financial education, girls learn critical money-management skills that help them set goals and build savings, and learn budgeting and negotiating skills. Finally, through a stable girls group that meets regularly, under the guidance of a young woman role model, girls build critical social networks in their communities, developing safety nets, confidence, and communication skills that help them navigate the dynamic and often risky world around them. A combination of institutions partnering to deliver this array of social, health, and economic asset-building activities can make a difference in girls' lives in addition to achieving their own mission-whether it be providing financial services or reaching youth populations-or even both. 


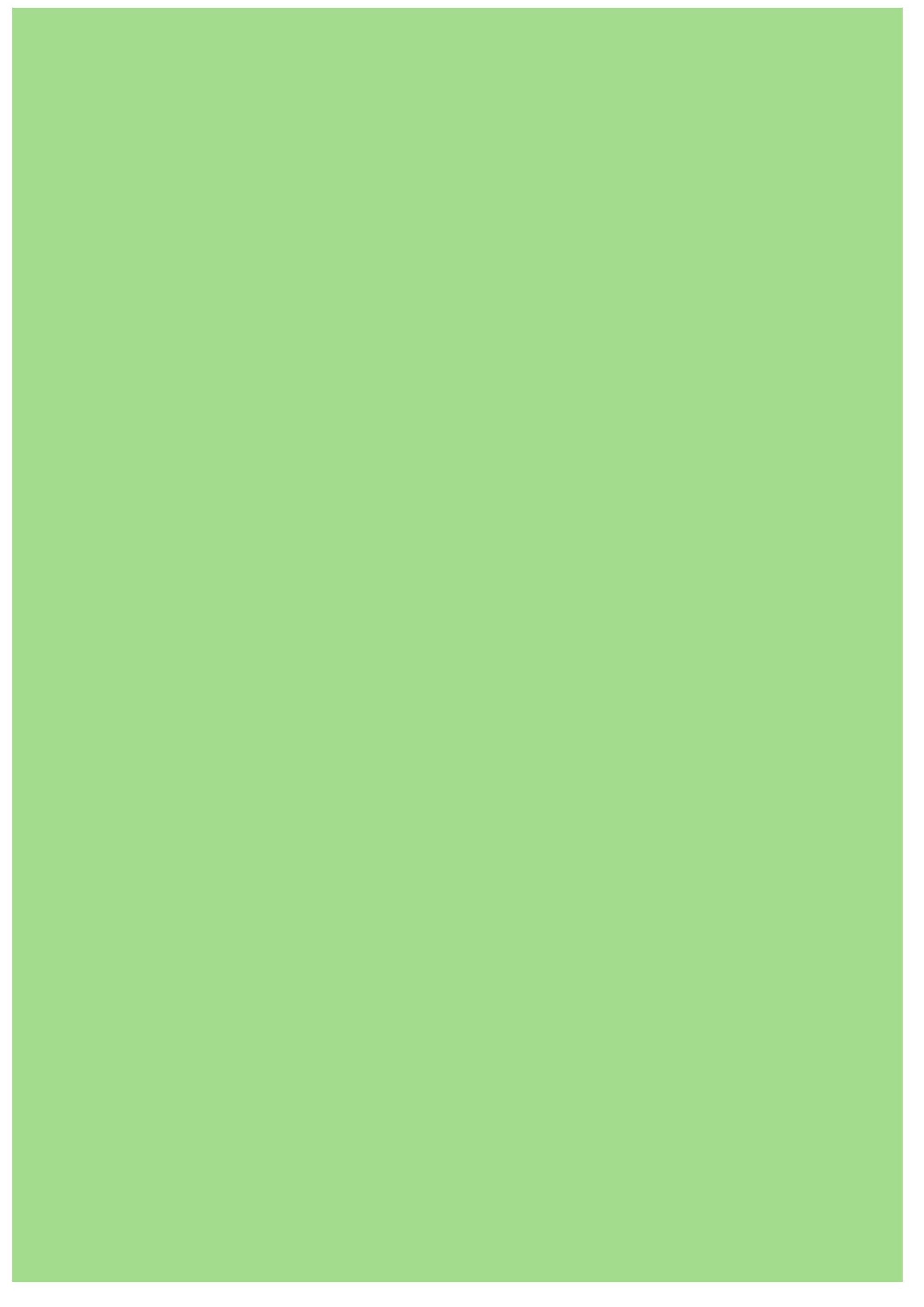

